\title{
Direct detection of Prevotella intermedia and $P$. nigrescens in suppurative oral infection by amplification of $16 S$ rRNA gene
}

\author{
S. STUBBS, S. F. PARK*, P. A. BISHOP $\dagger$ and M. A. O. LEWIS $\dagger$ \\ Anaerobe Reference Unit, University Hospital of Wales, Cardiff, * School of Biological Sciences, University of \\ Surrey, Guildford and †Oral Surgery, Medicine and Pathology, University of Wales College of Medicine, Cardiff
}

\begin{abstract}
A specific 16S rDNA PCR and subsequent hybridisation reaction was designed to discriminate between strains of Prevotella intermedia $(n=15)$ and $P$. nigrescens $(n=15)$. This technique was then used to detect the presence of these two bacterial species in acute suppurative oral infection. A total of 36 pus samples aspirated from 26 peri-apical abscesses, three root canals, three periodontal abscesses, two cases of refractory periodontitis, one cyst and one haematoma was examined. A portion of the pus sample was processed by PCR and the remainder of the specimen was subjected to routine culture. The PCR-based technique gave an identical pattern of detection of $P$. intermedia or $P$. nigrescens to that obtained by culture for 30 of the 36 specimens. Either $P$. intermedia or $P$. nigrescens was present in 14 samples and neither species was detected in 16 samples. In the remaining six samples the PCR method indicated the presence of one $(n=3)$ or both $(n=3)$ of the Prevotella species but neither or only one species was isolated by culture. It is concluded that the presence of $P$. intermedia and $P$. nigrescens in pus can be detected rapidly and specifically by direct PCR amplification of $16 \mathrm{~S}$ rDNA. $P$. nigrescens was detected more frequently than $P$. intermedia in suppurative peri-apical infection both by culture and PCR.
\end{abstract}

\section{Introduction}

Pigmented species of Prevotella are frequently isolated from various oral and extra-oral infections $[1,2]$. Many such infections are suppurative, encompassing infected wounds and abscesses of the head, neck, thorax and abdomen [2]. $P$. intermedia and $P$. nigrescens have been the pigmenting anaerobes encountered most frequently in pleuropulmonary infections, gangrenous or perforative appendicitis and suppurative dental infection [1-5]. Furthermore, studies have reported the isolation of $P$. intermedia from active periodontal lesions and dentoalveolar abscesses, whereas $P$. nigrescens seems to be associated with endodontic infection and gingival sites in both health and disease [2, 6-9].

Conventional biochemical tests do not discriminate between $P$. intermedia and $P$. nigrescens reliably, although these species can be differentiated by cellular protein profiles [7], malate and glutamate dehydrogen-

Received 18 Feb. 1999; revised version accepted 20 April 1999.

Corresponding author: $\operatorname{Dr}$ M. A. O. Lewis (e-mail: LewisMAO@cf.ac.uk). ase electrophoretic mobility $[10,11]$, PCR-restriction fragment length polymorphism (PCR-RFLP) [9], oligonucleotide probes $[11,12], 16 \mathrm{~S}$ rDNA sequencing [13], whole-cell DNA hybridisation [11], surface antigenicity [14] and ribotyping [15]. However, these techniques have several disadvantages, including expense, subjective interpretation of results, requirement for culture, lengthy process time, lack of sensitivity or the need for complex equipment $[11,12,14,16-18]$. Conventional microbiological processing of pus from oral infection requires prolonged primary anaerobic incubation for up to 7 days followed by subculture. Therefore, microbiological reports for acute dental infections often have little impact on clinical management, because of the late availability of culture results.

Traditionally, members of the penicillin group of antibiotics have been regarded as the agents of choice in the treatment of suppurative oral infection, because the majority of isolates from such infections have been found to be sensitive to these antimicrobial agents. However, the incidence of resistance to penicillin appears to be increasing. A multicentre study reported that one or more penicillin-resistant isolates were isolated from pus samples obtained from $43(55 \%)$ of 
78 patients with acute suppurative oral infections. Resistance was encountered most frequently among Prevotella spp., with $41(61 \%)$ of 67 isolates exhibiting resistance to penicillin [19]. To date, the presence of penicillin-resistant strains within the mixed flora of acute suppurative dental infection has rarely produced a clinical problem. However, an increased incidence of resistance in Prevotella spp. may have implications for patient management in the future, as these microorganisms have been shown to be the major pathogens in the mixed flora of acute dentoalveolar abscess [20].

A method for detecting the presence of certain Prevotella spp. and, therefore, the possibility of penicillin resistance, may be helpful, particularly in cases where the patient fails to respond within the first $48 \mathrm{~h}$ of initial therapy. Two recent studies have reported the detection and differentiation of $P$. intermedia and $P$. nigrescens in dental plaque with the $16 \mathrm{~S}$ rRNA gene as a target for PCR $[8,17]$. However, this approach has not been applied to pus from acute suppurative oral infections. Therefore, the aim of the present study was to develop a novel single-step PCR reaction, targeted to the $16 \mathrm{~S}$ rRNA gene, to allow rapid detection of $P$. intermedia and $P$. nigrescens in suppurative oral infections.

\section{Materials and methods}

\section{Bacterial culture and identification of test strains}

Bacteria were maintained on Fastidious Anaerobe Agar (FAA; Lab M, Amersham) supplemented with sheep blood $5 \% \mathrm{v} / \mathrm{v}$ in an anaerobic atmosphere $\left(\mathrm{CO}_{2} 10 \%\right.$, $\mathrm{H}_{2} 10 \%, \mathrm{~N}_{2} 80 \%$ ) at $37^{\circ} \mathrm{C}$. The identity of strains of $P$. intermedia and $P$. nigrescens (Table 1), isolated from various oral and non-oral sites, had been confirmed previously by biochemical analysis, electrophoretic enzyme analysis, 16S rDNA sequencing, SDS-PAGE protein profiling and 16S rDNA PCR-RFLP [9$11,13,21]$. Further strains were analysed to detect possible cross-reactivity in the PCR assay. These included: $P$. corporis $\mathrm{R} 8579$ (facial wound), $P$. oris ATCC $33573^{\mathrm{T}}, P$. denticola $\mathrm{R} 9102$ (oral isolate), $P$. loescheii NCTC $11321^{\mathrm{T}}$, Porphyromonas gingivalis W50 (periodontal pocket; H. Shah, Eastman Dental School, London), Por. levii NCTC $11028^{\mathrm{T}}$, Por. endodontalis R8754 (oral abscess), Por asaccharolytica NCTC 9337 (haemorrhoid) and R9170 (gangrenous scrotum), Fusobacterium nucleatum C81496 and C2796 (dental abscess), Eubacterium timidum ATCC $33093^{\mathrm{T}}$, Propionibacterium acnes NCTC $737^{\mathrm{T}}$, Peptostreptococcus anaerobius NCTC $11460^{\mathrm{T}}$, Streptococcus constellatus $\mathrm{C} 27496$ and $\mathrm{C} 22897$ (dental abscess), S. anginosis $\mathrm{C} 50095$ and $\mathrm{C} 38397$ (dental abscess), $S$. intermedius C4896, Actinomyces israelii C886 (dental plaque), C2796 and C38297 (dental abscess), $S$. agalactiae C22297 (dental abscess), Eikenella corrodens C22397 (oral isolate), Pseudomonas aeruginosa C29197 (dental abscess) and Candida albicans C22297
Table 1. Identity and origin of isolates of $P$. intermedia and $P$. nigrescens used to validate PCR and hybridisation reactions

\begin{tabular}{|c|c|c|}
\hline Species & Isolate no. & Origin \\
\hline$P$ intermedia & $\begin{array}{l}\text { ATCC } 25611^{\mathrm{T}} \\
\text { OMZ } 311 \\
\text { OMZ } 326 \\
\text { SF } 10254 \\
\text { BH } 20-30 \\
\text { DAL } 100 \\
\text { R } 15 \\
\text { R } 22 \\
\text { R } 78 \\
\text { C } 66395 \\
\text { C } 22996 \\
\text { C } 56696 \\
\text { C } 78596 \\
\text { C } 10997 \\
\text { C } 16697\end{array}$ & $\begin{array}{l}\text { Empyema } \\
\text { Periodontal pocket } \\
\text { Transtracheal aspirate } \\
\text { Empyema } \\
\text { Supragingival plaque } \\
\text { Dental plaque } \\
\text { Peri-apical abscess } \\
\text { Peri-apical abscess } \\
\text { Peri-apical abscess } \\
\text { Peri-apical abscess } \\
\text { Peri-apical abscess } \\
\text { Peri-apical abscess } \\
\text { Infected salivary gland } \\
\text { Rapidly progressive periodontitis } \\
\text { Periodontal pocket }\end{array}$ \\
\hline$P$. nigrescens & $\begin{array}{l}\text { ATCC } 33563^{\mathrm{T}} \\
\text { DAL } 10 \\
\text { T } 588 \\
\text { SF } 10256 \\
\text { BH } 18-23 \\
\text { MUI } 32 \\
\text { R } 20 \\
\text { R } 35 \\
\text { R } 53 \\
\text { K } 65 \\
\text { K } 79 \\
\text { R } 119 \\
\text { C } 6996 \\
\text { C } 7796 \\
\text { C } 76396\end{array}$ & $\begin{array}{l}\text { Vincent's gingivitis } \\
\text { Dental plaque } \\
\text { Dental plaque } \\
\text { Transtracheal aspirate } \\
\text { Periodontal pocket } \\
\text { Rapidly progressive periodontitis } \\
\text { Peri-apical abscess } \\
\text { Peri-apical abscess } \\
\text { Peri-apical abscess } \\
\text { Peri-apical abscess } \\
\text { Peri-apical abscess } \\
\text { Peri-apical abscess } \\
\text { Peri-apical abscess } \\
\text { Peri-apical abscess } \\
\text { Peri-apical abscess }\end{array}$ \\
\hline
\end{tabular}

(oral isolate). Strains designated $\mathrm{R}$ were obtained from the Anaerobe Reference Unit, Cardiff and those designated $\mathrm{C}$ were from the Oral Microbiology Department, Dental School, Cardiff. All strains were identified according to methods documented in the VPI manual [22] and subsequent updates.

\section{Nucleic acid preparation}

Crude template nucleic acid was prepared by boiling 1 volume of bacterial cells (harvested after 40-h culture on FAA) in 10 volumes of a $5 \% \mathrm{w} / \mathrm{v}$ solution of Chelex-100 (BioRad, Hemel Hempstead) for $10 \mathrm{~min}$ [23]. The solution was centrifuged $(12000 \mathrm{~g}, 15 \mathrm{~min})$ and $5 \mu \mathrm{l}$ of supernate were assayed by PCR. The suitability of the nucleic acid extract for PCR was assessed with the universal eubacterial 16S rDNA primers pA (5' AGAGTTTGATCCTGGCTCAG; 8-27, Escherichia coli numbering) and gamma (5' ACTGCTGCCTCCCGTAGGAG; 358-339), as described previously [24].

\section{$16 S$ rDNA specific PCR}

Two pairs of diagnostic PCR primers were designed to the respective $16 \mathrm{~S}$ rRNA genes of $P$. intermedia (Pit1, 5' CAAAGATTCATCGGTGGA; 245-262: Pit2, 5' GCCGGTCCTTATTCGAAG; 551-534) and $P$. nigrescens (Png1, 5' CAAAGGTTTTCCGGTAAG; 245- 
262: Png2, 5' GCCGGTCCTTATTCATGA; 551-534), with significant $3^{\prime}$ sequence mismatch to non-homologous templates. Cross-reactivity of primers and probes with $16 \mathrm{~S}$ rRNA genes from related species was assessed by multiple alignment, and reduced further by a BlastN homology search (Internet address: $\mathrm{Hp}: / /$ www.dispatchl.nlm.nih.gov) of the EMBL database. Nucleic acid extract was added to a $50-\mu 1$ PCR reaction mixture $(10 \mathrm{mM}$ Tris- $\mathrm{HCl}, \mathrm{pH} 8.3 ; 1.5 \mathrm{mM}$ $\mathrm{MgCl}_{2} ; 50 \mathrm{mM} \mathrm{KCl}$; gelatin $0.01 \% ; 125 \mu \mathrm{M}$ each dNTP; $1 \mathrm{U}$ Taq DNA polymerase, Promega, Southampton) containing either the $P$. intermedia or $P$. nigrescens specific primer pair $(0.18 \mu \mathrm{M})$. Reaction mixtures were denatured for $3 \mathrm{~min}$ at $94^{\circ} \mathrm{C}$, and subjected to 30 cycles of denaturation at $94^{\circ} \mathrm{C}$ for $45 \mathrm{~s}$, annealing at $50^{\circ} \mathrm{C}$ for $1 \mathrm{~min}$ and polymerisation at $72^{\circ} \mathrm{C}$ for $1 \mathrm{~min}$. Amplification products were resolved by agarose $(2 \% \mathrm{w} / \mathrm{v})$ gel electrophoresis in TAE buffer $(40 \mathrm{~mm}$ Tris-acetate buffer, 1 mM EDTA, pH 8.0) and visualised by washing for $20 \mathrm{~min}$ in a solution of ethidium bromide $0.5 \mu \mathrm{g} / \mathrm{ml}$. The sensitivity of the reaction was determined by amplification of serially diluted genomic DNA (range $5 \mathrm{fg}-500 \mathrm{ng}$ ) that had been prepared from the respective type strain of each species by the method of Pitcher et al. [25] and quantified by absorbance measurement at $260 \mathrm{~nm}$ (GeneQuant; Pharmacia, Amersham). In addition, PCR products generated from the type strains of $P$. intermedia and $P$. nigrescens were cleaned with QIAquick-spin PCR clean-up columns (Qiagen, Crawley, West Sussex) and product identity and size were determined by sequencing with the ABI-PRISM Dye Terminator Cycle Sequencing kit (Perkin-Elmer, Warrington).

\section{Southern blotting and hybridisation}

The identity of all PCR products was confirmed by oligonucleotide hybridisation with internal 5' biotinylated probes Pit3 (5' CTTTTGTTGGGGAGTA; 479494) and Png3 (5' CTTTTATGTGGGAATAAA; 479496) specific for the $16 \mathrm{~S}$ rRNA genes of $P$. intermedia and $P$. nigrescens, respectively. DNA transfer, hybridisation, washing and visualisation were performed with the Sure Blot ${ }^{\mathbb{R}}$ Blue Southern kit according to the manufacturer's instructions (Oncor, Gaithersburg, MD, USA). A minor modification to the standard protocol involved removing non-specifically bound probe by washing the membrane three times in $2 \times \mathrm{SSC}$ at room temperature for $15 \mathrm{~min}$, followed by two stringency washes in $2 \times \mathrm{SSC}$ at $42^{\circ} \mathrm{C}$ for $15 \mathrm{~min}$.

\section{Processing of clinical samples}

Pus specimens aspirated from peri-apical abscesses $(\mathrm{n}=26)$, infected root canals $(3)$, infected haematoma (1), infected cyst (1) and periodontal abscesses (3), and plaque samples from two patients with rapidly progressive periodontitis were examined. Duplicate $10-\mu \mathrm{l}$ volumes of sample were added directly to $90 \mu \mathrm{l}$ of Chelex-100 5\% and nucleic acid was extracted and analysed as above. The remainder of the specimen was processed routinely with traditional culture techniques. Briefly, samples were inoculated on to FAA-blood media, incubated in an anaerobic atmosphere and examined for growth every $24 \mathrm{~h}$ over a 7 -day period [3]. Six black-pigmented colonies were selected from each primary plate and subcultured for purity. Isolates were identified as either $P$. intermedia or $P$. nigrescens by enzyme electrophoresis $[10,21]$ and by direct PCR as described above.

\section{Results}

\section{Validation of PCR method}

Results of PCR reactions with primer pairs specific for $P$. intermedia and $P$. nigrescens are shown in Fig. la and $\mathrm{c}$, respectively. PCR with the $P$. intermedia primer pair produced an amplification product (size $296 \mathrm{bp}$ ) with all 15 strains of $P$. intermedia isolated from various oral and non-oral sites but not with strains of $P$. nigrescens or other similar organisms. $P$. intermedia SF 10254 (a strain producing an atypical cellular protein profile) and a highly proteolytic strain, $P$. intermedia R78 [21], also yielded the specific amplification product. All 15 strains of $P$ nigrescens produced a detectable product (size $291 \mathrm{bp}$ ) with the primer pair for this species and no cross-reactivity was observed with strains of $P$. intermedia or similar taxa. The identity of all PCR products was confirmed by specific oligonucleotide hybridisation (Fig. $1 \mathrm{~b}$ and $\mathrm{d}$, respectively). The sensitivity of the $P$. intermedia and the $P$. nigrescens specific PCR was 5 pg of genomic DNA and sensitivity was increased 10 -fold (to $500 \mathrm{fg}$ ) with oligonucleotide hybridisation.

\section{Analysis of clinical samples by culture and PCR}

Routine culture yielded three isolates of $P$. intermedia and 12 isolates of $P$. nigrescens from 15 samples (Table 2). Chelex-extracted nucleic acid from clinical pus samples provided template suitable for amplification allowing direct detection and discrimination of $P$. intermedia and $P$. nigrescens (Table 2); six samples were PCR-positive for $P$. intermedia and 16 for $P$. nigrescens.

PCR (with subsequent hybridisation) and traditional culture were in agreement for 30 of the 36 pus specimens examined. Discrepancies between the methods occurred in six samples; three yielded PCR product indicating the presence of $P$ intermedia or $P$. nigrescens, but neither species was isolated by culture, and three yielded products indicating the presence of both species, whereas culture yielded only one or neither species. All samples that yielded $P$. intermedia or $P$. nigrescens in culture also gave positive results in the PCR.

$P$. nigrescens was detected more frequently than 


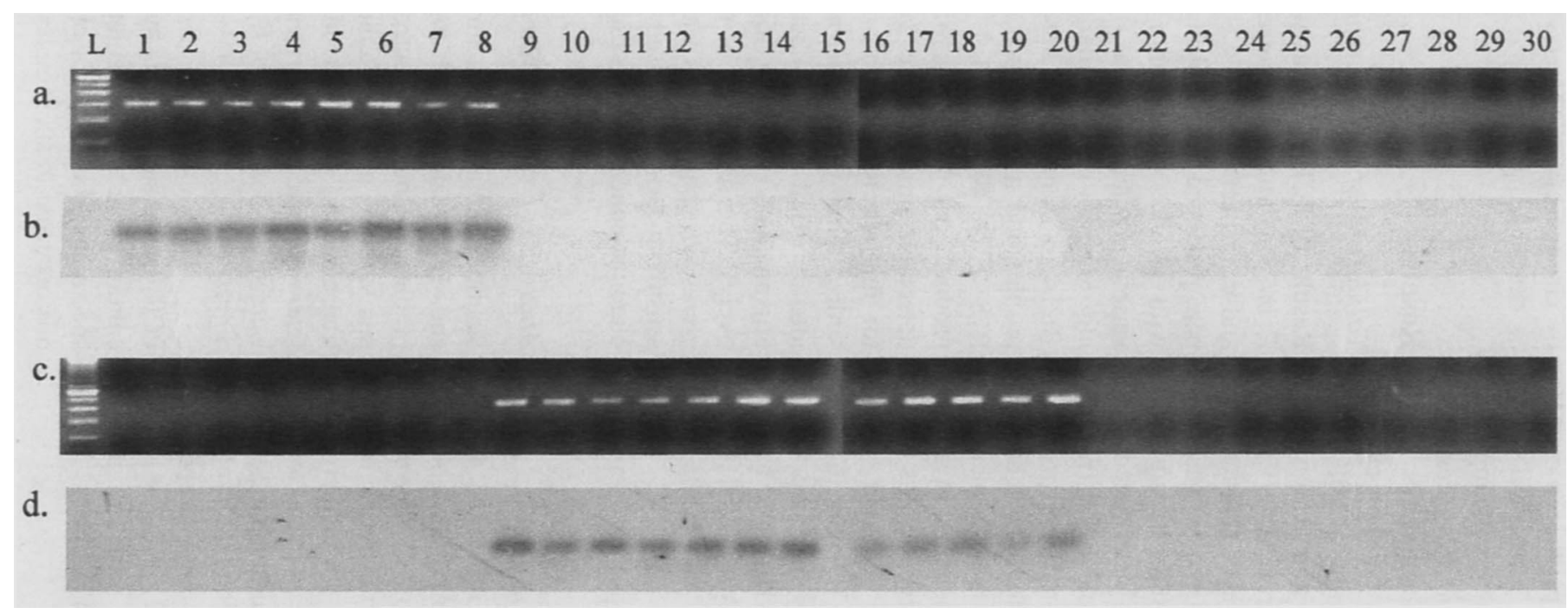

Fig. 1. Amplification products obtained with (a) P. intermedia specific primers, Pitl and Pit2, and (c) P. nigrescens specific primers, Png1 and Png2. Confirmation of PCR product identity by hybridisation with (b) $P$. intermedia specific biotinylated probe Pit3, and (d) P. nigrescens specific biotinylated probe Png3. Lanes: L, 1-kb marker (Gibco BRL, Paisley); 1-8, strains of $P$. intermedia; 9-20, strains of P. nigrescens; 21, P. corporis; 22, P. oris; 23, P. denticola; 24, P. loescheii; 25, Por. gingivalis; 26, Por. levii; 27, Por. endodontalis; 28 and 29, Por. asaccharolytica; 30, water. 
Table 2. Identity of $P$. intermedia and $P$. nigrescens detected by culture and PCR in 36 suppurative oral infections

\begin{tabular}{|c|c|c|c|}
\hline \multirow{2}{*}{$\begin{array}{l}\text { Sample } \\
\text { no. }\end{array}$} & \multirow[b]{2}{*}{ Infection } & \multicolumn{2}{|c|}{ Presence of Prevotella } \\
\hline & & Culture & PCR \\
\hline $1074 / 96$ & Peri-apical abscess & $\mathrm{Pi}$ & $\mathrm{Pi}$ \\
\hline $182 / 97$ & Periodontal abscess & $\operatorname{Pn}$ & $\mathrm{Pn}$ \\
\hline $183 / 97$ & Peri-apical abscess & $\mathrm{Pi}$ & $\mathrm{Pi}$ \\
\hline $228 / 97$ & Root canal & - & - \\
\hline $236 / 97$ & Peri-apical abscess & - & Pn \\
\hline $285 / 97$ & Peri-apical abscess & - & - \\
\hline $286 / 97$ & Root canal & Pn & Pn \\
\hline $289 / 97$ & Peri-apical abscess & Pn & $\operatorname{Pn}$ \\
\hline $303 / 97$ & Peri-apical abscess & - & - \\
\hline $307 / 97$ & Peri-apical abscess & Pn & $\mathrm{Pn}$ \\
\hline $330 / 97$ & Periodontal abscess & - & Pn \\
\hline $355 / 97$ & Peri-apical abscess & Pn & Pn \\
\hline $356 / 97$ & Dental cyst & - & - \\
\hline $361 / 97$ & Root canal & - & - \\
\hline $366 / 97$ & Haematoma & - & - \\
\hline $376 / 97$ & Peri-apical abscess & - & $\mathrm{Pi}$ \\
\hline $382 / 97$ & Peri-apical abscess & - & - \\
\hline $383 / 97$ & Peri-apical abscess & Pn & Pn \\
\hline $399 / 97$ & Peri-apical abscess & $\mathrm{Pn}$ & $\mathrm{Pn}$ \\
\hline $408 / 97$ & Peri-apical abscess & $\operatorname{Pn}$ & Pn \\
\hline $423 / 97$ & Peri-apical abscess & - & - \\
\hline $437 / 97$ & Periodontal abscess & - & - \\
\hline $480 / 97$ & Peri-apical abscess & Pn & Pn \\
\hline $481 / 97$ & Peri-apical abscess & $\mathrm{Pn}$ & $\mathrm{Pn}$ \\
\hline $499 / 97$ & Peri-apical abscess & - & - \\
\hline $504 / 97$ & Refractory periodontitis & $\mathrm{Pi}$ & $\mathrm{Pi}+\mathrm{Pn}$ \\
\hline $513 / 97$ & Peri-apical abscess & - & - \\
\hline $515 / 97$ & Peri-apical abscess & - & $\mathrm{Pi}+\mathrm{Pn}$ \\
\hline $534 / 97$ & Refractory periodontitis & Pn & Pn \\
\hline $545 / 97$ & Peri-apical abscess & - & - \\
\hline $547 / 97$ & Peri-apical abscess & - & - \\
\hline $548 / 97$ & Peri-apical abscess & - & - \\
\hline $549 / 97$ & Peri-apical abscess & - & - \\
\hline $554 / 97$ & Peri-apical abscess & Pn & $\mathrm{Pi}+\mathrm{Pn}$ \\
\hline $558 / 97$ & Peri-apical abscess & - & - \\
\hline $566 / 97$ & Peri-apical abscess & - & - \\
\hline
\end{tabular}

$\mathrm{Pi}$, P. intermedia $; \mathrm{Pn}$, P. nigrescens; -, neither detected.

$P$. intermedia by both methods. In endodontic and periapical infections $(\mathrm{n}=29)$, the prevalence of $P$. nigrescens $(\mathrm{n}=10$ in culture or 12 by $\mathrm{PCR}$ ) was greater than $P$. intermedia $(\mathrm{n}=2$ in culture or 5 by PCR).

\section{Discussion}

Although $P$. intermedia and $P$ nigrescens exhibit exceptional phenotypic similarity, there are distinct genotypic differences. Recognised techniques for the reliable identification of these organisms are not readily applicable to large-scale clinical studies or in smaller laboratories [9]. However, previous PCR-based studies have indicated that simple, rapid methods for discriminating $P$. intermedia and $P$. nigrescens are helpful in providing information on the relative roles of these two strict anaerobes in oral disease $[8,17]$.

The PCR primers described in the present study discriminated $P$. intermedia and $P$. nigrescens both from one another and from other similar organisms. The identity of PCR products from strains of $P$. intermedia and $P$. nigrescens was confirmed subsequently by hybridisation with specific internal oligonucleotide probes. The overall sensitivity of the $P$. intermedia and $P$. nigrescens reactions was $500 \mathrm{fg}$ of target DNA, equating to a detection limit of c. 100 bacterial cells per reaction. In contrast to earlier reports $[8,17,18]$, the PCR technique used here did not require stringent annealing conditions to differentiate strains of $P$. intermedia and $P$. nigrescens. Primers were designed with significant mismatching ( $7 \mathrm{bp}$ with nonhomologous template) at the $3^{\prime}$ end of oligonucleotides, allowing PCR discrimination at a relatively low annealing temperature and standard $\mathrm{MgCl}_{2}$ concentration. Also, specific oligonucleotide probes were designed to contain 5-bp mismatches with the nonhomologous template, thereby reducing the possibility of cross-reaction and mis-diagnosis to a minimum.

Rapid nucleic acid preparation by boiling in Chelex100 resin has been reported to remove protein contamination, increase the stability of template [23] and reduce PCR inhibition [26] when compared with boiling in water alone. In the present study, Chelex100 -extracted nucleic acid from cultured bacteria and clinical pus and plaque samples provided template suitable for $16 \mathrm{~S}$ rDNA PCR with 'universal' primers targeted to $16 \mathrm{~S}$ rRNA gene sequences. Therefore, it would appear that inhibition of PCR by constituents of oral pus may not be a major problem. A combination of the simple template preparation technique with the specific PCR reaction permitted the direct, rapid detection and discrimination of $P$. intermedia and $P$. nigrescens in oral pus samples. This strategy gave a preliminary indication of the presence of $P$. intermedia or $P$. nigrescens, or both, in oral pus after only $4 \mathrm{~h}$ (confirmation by hybridisation after $24 \mathrm{~h}$ ).

Detection by PCR produced results analogous to traditional culture for the majority of samples (Table 2). However, a small number of discrepancies did occur and comparison with studies employing these techniques individually should be drawn with caution. Previous studies involving the detection of Por. gingivalis in saliva and plaque have reported clear differences between the findings of culture and those obtained by PCR $[17,26]$. Such discrepancies have been attributed to the presence of DNA from nonviable organisms remaining available for amplification, the higher sensitivity of PCR and the possible loss of slower-growing organisms during culture due to the overgrowth of other bacteria. In the present study, six pigmented colonies were taken from the primary plate for subculture according to routine practice. However, colonies of $P$. intermedia and $P$. nigrescens have a similar appearance and colony type is not helpful in distinguishing between the two species. It is not practical to subculture all pigmented colonies on the primary plate and, therefore, it is possible that one of the species may have been undetected by culture. The PCR method detected the presence of $P$. intermedia 
and $P$. nigrescens on each occasion it was cultured from the pus sample. The PCR detection of additional strains in six samples highlights the advantage of the method over routine diagnostic culture methods.

Despite the small number of samples included in the present study, the relative occurrence of $P$. intermedia and $P$. nigrescens indicates that $P$. nigrescens may be more likely to be encountered in suppurative oral infections. These results would support the association of $P$. nigrescens with endodontic and peri-apical abscess infections which has been reported previously $[7,8,27]$.

Penicillins remain the antibiotic group of choice in the treatment of acute suppurative oral infection despite the increased incidence of penicillin resistance in strains of Prevotella spp. [19]. The PCR-based method described here has the potential to provide useful information to the clinician, as rapid detection of the presence of $P$. intermedia and $P$. nigrescens would give an early indication of the likelihood of penicillin-resistant strains in the infection if a patient was failing to respond to initial antimicrobial therapy.

We thank Dr H. N. Shah (CPHL, Colindale, London) for kindly supplying a number of bacterial strains and Dr J. T. Magee for help during the preparation of the manuscript. This work was funded by Colgate Palmolive through the Oral and Dental Research Trust. S.S. was funded by the MRC.

\section{References}

1. Finegold SM, Strong CA, McTeague M, Marina $M$. The importance of black-pigmented gram-negative anaerobes in human infections. FEMS Immunol Med Microbiol 1993; 6 $77-82$.

2. Mättö J, Asikainen S, Väisänen M-L et al. Role of Porphyromonas gingivalis, Prevotella intermedia, and Prevotella nigrescens in extraoral and some odontogenic infections. Clin Infect Dis 1997; 25 Suppl 2: S194-S198.

3. Lewis MAO, MacFarlane TW, McGowan DA. Quantitative bacteriology of acute dento-alveolar abscesses. $J$ Med Microbiol 1986; 21: 101-104.

4. Sundqvist G. Associations between microbial species in dental root canal infections. Oral Microbiol Immunol 1992; 7: $257-262$.

5. Haapasalo M. Black-pigmented gram-negative anaerobes in endodontic infections. FEMS Immunol Med Microbiol 1993; 6 $213-217$.

6. Dahlén $\mathrm{G}$, Wikström $\mathrm{M}$, Renvert $\mathrm{S}$, Gmür R, Guggenheim B Biochemical and serological characterization of Bacteroides intermedius strains isolated from the deep periodontal pocket. $J$ Clin Microbiol 1990; 28: 2269-2274.

7. Gharbia SE, Haapasalo M, Shah HN et al. Characterization of Prevotella intermedia and Prevotella nigrescens isolates from periodontic and endodontic infections. J Periodontol 1994; 65: $56-61$

8. Conrads G, Mutters R, Fischer J, Brauner A, Lutticken R, Lampert F. PCR reaction and dot-blot hydridization to monito the distribution of oral pathogens within plaque samples of periodontally healthy individuals. $J$ Periodontol 1996; 67: 995- 1003 .

9. Milsom SE, Sprague SV, Dymock D, Weightman AJ, Wade WG. Rapid differentiation of Prevotella intermedia and $P$ nigrescens by $16 \mathrm{~S}$ rDNA PCR-RFLP. $J$ Med Microbiol 1996; 44: $41-43$

10. Shah HN, Gharbia SE. Biochemical and chemical studies on strains designated Prevotella intermedia and proposal of a new pigmented species, Prevotella nigrescens. sp. nov. Int $J$ Syst Bacteriol 1992; 42: 542-546.

11. Frandsen EVG, Poulsen K, Kilian M. Confirmation of the species Prevotella intermedia and Prevotella nigrescens. Int $J$ Syst Bacteriol 1995; 45: 429-435.

12. Shah HN, Gharbia SE, Scully C, Finegold SM. Oligonucleotide probes to the $16 \mathrm{~S}$ ribosomal RNA: implications of sequence homology and secondary structure with particular reference to the oral species Prevotella intermedia and Prevotella nigrescens. Oral Dis 1995; 1: 32-36.

13. Paster BJ, Dewhirst FE, Olsen I, Fraser GJ. Phylogeny of Bacteroides, Prevotella, and Porphyromonas spp. and related bacteria. J Bacteriol 1994; 176: 725-732.

4. Gmür R, Guggenheim B. Antigenic heterogeneity of Bacteroides intermedius as recognized by monoclonal antibodies. Infect Immun 1983; 42: 459-470.

15. Dahlén GD, Johnson JR, Gmür R. Prevotella intermedia and Prevotella nigrescens serotypes, ribotypes and binding characteristics. FEMS Microbiol Lett 1996; 138: 89-96.

16. Gmür R, Guggenheim B. Interdental supragingival plaque - a natural habitat of Actinobacillus actinomycetemcomitans, Bacteroides forsythus, Campylobacter rectus, and Prevotella nigrescens. J Dent Res 1994; 73: 1421-1428.

17. Ashimoto A, Chen C, Bakker I, Slots J. Polymerase chain reaction for the detection of 8 putative periodontal pathogens in subgingival plaque of gingivitis and advanced periodontal lesions. Oral Microbiol Immunol 1996; 11: 266-273.

18. Conrads G, Pelz K, Hughes B, Seyfarth I, Devine DA. Optimized oligonucleotides for the differentiation of Prevotella intermedia and Prevotella nigrescens. Oral Microbiol Immunol 1997; 12: 117-120.

19. Lewis MAO, Pankhurst CL, Douglas CWI et al. Prevalence of penicillin resistant bacteria in acute suppurative oral infection J Antimicrob Chemother 1995; 35: 785-791.

20. Lewis MAO, MacFarlane TW, McGowan DA, MacDonald DG Assessment of the pathogenicity of bacterial species isolated from acute dentoalveolar abscesses. $J$ Med Microbiol 1988; 27: $109-116$

21. Stubbs S, Lewis MAO, Waddington RJ, Embery G. Hydrolytic and depolymerising enzyme activity of Prevotella intermedia and Prevotella nigrescens. Oral Dis 1996; 2: 272-278.

22. Holdeman LV, Moore WEC, Cato EP (eds). Anaerobe laboratory manual, 4th edn and updates. Blacksburg, Virginia, Anaerobe Laboratory. 1977.

23. de Lamballerie $X$, Zandotti C, Vignoli C, Bollet $C$, de Micco P. A one-step microbial DNA extraction method using "Chelex 100 " suitable for gene amplification. Res Microbiol 1992; 143 785-790.

24. Hutson RA, Thompson DE, Collins MD. Genetic interrelationships of saccharolytic Clostridium botulinum types B, E and F and related clostridia as revealed by small-subunit rRNA sequences. FEMS Microbiol Lett 1993; 108: 103-110.

25. Pitcher DG, Saunders NA, Owen RJ. Rapid extraction of bacterial genomic DNA with guanidium thiocyanate. Lett Appl Microbiol 1989; 8: 151-156.

26. Mättö J, Saarela M, Alaluusua $\mathrm{S}$ et al. Detection of Porphyromonas gingivalis from saliva by PCR by using a simple sample-processing method. J Clin Microbiol 1998; 36: $157-160$.

27. Bae KS, Baumgartner JC, Shearer TR, David LL. Occurrence of Prevotella nigrescens and Prevotella intermedia in infections of endodontic origin. $J$ Endod 1997; 23: 620-623. 